\title{
HOW BOONESBORO LOST A RAILROAD STATION
}

\section{By Alonzo J. Barkley}

In May, 1856, congress passed "The Iowa Land Bill," granting lands to the state of Iowa, to aid in the construction of four lines of railroad across the state. One of these lines was to run northwesterly from Lyons, Iowa, to a point of intersection with the Iowa Central Railway, near Maquoketa, thence running as near as practicable on the forty-second parallel to the Missouri River.

The Iowa legislature, by an act approved July 14, 1856, granted the land inuring to the state for the construction of said line of railroad to the Iowa Central Air Line Railroad Company, upon certain conditions named in the act. The great panic of 1857 put this company entirely out of business. In March, 1860 , the state resumed the grant and made it over to the Cedar Rapids and Missouri River Railroad Company, a company organized June 14, 1859, and composed largely of stockholders in the Chicago, Iowa and Nebraska Railroad Company, already in operation from Clinton to Cedar Rapids, Iowa. The Cedar River was bridged at Cedar Rapids and the railroad built west to Otter Creek in 1860 and 1861 , to Marshalltown in 1862, to State Center in 1863, to Nevada by July 4, 1864, and the track laid to Boone in December, 1864, but the road was not surfaced up and completed from Nevada to Boone until 1865 .

On March 28, 1865, the town plat of the town of Boone was filed for record by John I. Blair, who had previously purchased a large portion of the land where the city of Boone is now located.

The railroad was built from Marshalltown to the Missouri River, under the management of John I. Blair, and W. W. Walker $^{1}$ was his chief engineer.

In July, 1862, the Cedar Rapids and Missouri River Railroad was leased in perpetuity to the Galena and Chicago Union Railroad Company, which company then owned the line from Chicago west to the Mississippi River, opposite Clinton, Iowa, and operated the Chicago, Iowa and Nebraska Railroad under lease. The

\footnotetext{
${ }^{1}$ Mr. Walker's widow resides in Cedar Rapids with her daughter, Mrs. A. W. Lee. Her younger daughter, Mrs. Johnson Brigham, resides in Des Moines.
} 
lease covered not only the portion of the Cedar Rapids and Missouri River Railroad then built, but the entire line to the Missouri River, when the same should be completed to some point on said river.

On June 2, 1864, the Galena and Chicago Union Railroad was consolidated with the Chicago and North Western Railway and from that time the operation of the Cedar Rapids and Missouri River Railroad, under the lease, was by the Chicago and North Western Railway Company.

During the time the railroad was being built westward from Cedar Rapids across the state, it was uncertain in the minds of our people in Boone County just when and where the railroad would be built across the west half of the state, and at what point it would touch the Missouri River. Owing to this uncertainty its promoters were enabled to secure some local aid through the counties which it finally passed. Our people wanted an outlet for their products and had already abandoned all hope of ever getting transportation by way of the Des Moines River, which they felt could never be made navigable, except during the high water stages-lasting a few weeks in the spring and fall. Their anxiety was so great that Mr. Walker induced Boone County to donate its swamp land funds and its unsold swamp lands to the Cedar Rapids and Missouri River Railroad, on condition that it build its road through this county. The contract was to be void in case the road was not built ten miles west from the east line of the county, within a certain fixed time. This contract was ratified by the voters of Boone County at a special election held soon after for that purpose.

Boonesboro wanted a depot, and to this end an agreement was made, and the $\$ 10,000$ bonus asked by the company was finally raised, part in cash and part in notes. Several "railroad meetings" had been held in Boonesboro to arouse the people and secure this subscription. Mr. Walker not being satisfied with this arrangement, asked that the notes be guaranteed by responsible parties, which for some reason was not done within the time specified.

During the last of those "railroad meetings" held in the old courthouse for the purpose of raising the subscription to secure the depot, a little incident occurred that may be of interest to 
some of the old settlers, who looked upon the location of a depot in Boonesboro as a foregone conclusion. Mr. Blair and $\mathrm{Mr}$. Walker were in attendance at that meeting and Mr. Walker was called upon to explain certain matters under discussion. Hardly had he begun to talk when a man, who had been largely instrumental in calling this meeting, was seen to walk quietly out of room. Mr. Walker, glancing at his overcoat which hung across the back of his chair, noticed that a package of papers had been taken from its pocket. Cutting his remarks short, he at once picked up his coat and, beckoning Mr. Blair, they walked out of the building and, in a very short time, drove rapidly away toward Des Moines. Before showing up again they purchased lands a mile or more east of the courthouse and subsequently located the depot almost a mile and one-half northeast of the public square in Boonesboro, and located the town of Boone on lands purchased for that purpose.

About three years later the man who carried off Mr. Walker's papers told the writer of this article that he went directly to the office of Jackson Orr, a prominent citizen of the county, where together they examined the sequestered papers and found them to be plats and surveys, showing the depot located about where it now stands, and a line of railroad running down a swale to Honey Creek, thence down this creek to the Des Moines River, leaving Boonesboro entirely to one side.

The finances of the company were not at that time sufficient to warrant its acceptance of the donation raised and the building of its road through Boonesboro, crossing the Des Moines River over such an expensive viaduct as the one now spanning the river on the main line of the Chicago and North Western Railway between Boone and Ogden. The large saving in the cost of building down Honey Creek and crossing the river at Moingona, in addition to the large profits subsequently realized from the sale of lots in the new town of Boone, might naturally lead one to the conclusion that at no time had the company seriously considered locating its depot in Boonesboro.

In July, 1864, congress made an additional land grant to the Ccdar Rapids and Missouri River Railroad and authorized it to change its line of road so as to connect with the proposed 
Union Pacific Railroad at Council Bluffs. The construction of the line west of Boone began late in $\mathbf{1 8 6 5}$ and the track was laid into Council Bluffs in January, 1867, but regular service from Woodbine to the Bluffs was not given until April, 1867.

In 1884 the Cedar Rapids and Missouri River Railroad was sold to the Chicago and North Western Railway. It was, in fact, a consolidation, but for convenience in handling it was made a sale.

The Iowa Railroad Land Company was organized in 1869 by the stockholders. of the Cedar Rapids and Missouri River Railroad. The land grant of that railroad company was conveyed to the Iowa Railroad Land Company September 15, 1869, and in 1887 the Iowa Railroad Land Company bought from the Iowa Falls and Sioux City Railroad Company its unsold lands.

The building of the Cedar Rapids and Missouri River Railroad Company being finished in 1867 , the grant was thus matured and perfected. However, it was not until 1902 that this grant was fully adjusted so that all tracts granted were definitely known and the companies given evidence of title thereto.

In June, 1871, the Blair Town Lot and Land Company took over the unsold town lots and the purchased lands along the road. It was consolidated with the Iowa Railroad Land Company in 1888.

The Moingona Coal Company was organized in June, 1866, and took over from the Cedar Rapids and Missouri River Railroad Company certain timber and coal lands, which had been acquired by that company in and near Moingona, and coal mines operated there for about twenty years, when the mines closed, and the unsold lands of this company were conveyed to the Iowa Railroad Land Company. 
Copyright of Annals of Iowa is the property of State of Iowa, by \& through the State Historical Society of Iowa and its content may not be copied or emailed to multiple sites or posted to a listserv without the copyright holder's express written permission. However, users may print, download, or email articles for individual use. 